\title{
Decoding the Disciplines as a Pedagogy of Teacher Education
}

\author{
ABSTRACT \\ This paper makes a conceptual argument for using the Decoding the Disciplines \\ research paradigm as a pedagogical innovation in the field of teacher education. It \\ incorporates empirical findings from a research project in which teacher candidates \\ conduct Decoding interviews to deepen understanding of historical thinking and \\ learn pedagogical practices. Results indicate teacher candidates benefitted from \\ conducting Decoding the Disciplines research and saw connections between that \\ research and their future practice.
}

\section{KEYWORDS}

Decoding the Disciplines, teacher education, disciplinary thinking, historical thinking

\section{INTRODUCTION}

Decoding the Disciplines has for years helped expert thinkers "decode" their discipline's epistemology and identify "bottlenecks" that impede student progress toward expert disciplinary thought (Middendorf and Shopkow 2018; Pace 2017, 2021; Pace and Middendorf 2004). Although developed in the context of higher education, this research and teaching paradigm holds value for $\mathrm{K}-16$ instruction. Pace (2017) has suggested Decoding might develop "a new language of teaching and learning that would lessen the negative impact of the current dysfunctional chasm between secondary and higher education" (134). However, K-12 education has only slowly adopted Decoding; numerous Decoding studies exist for fields in higher education, but few in K-12 teaching or K-12 teacher education.

University-based teacher education courses provide one place to address this chasm between secondary and higher education. This case study investigates training secondary history teacher candidates (TCs) in the Decoding paradigm as part of an undergraduate professional preparation course. In this course (which I taught), TCs conducted a small Decoding project that involved interviewing undergraduate students in a world history survey course. In those Decoding interviews, candidates elicited students' thinking on how they selected credible sources for history research papers. This case study examined what TCs learned from that experience. The following research questions guided the case study:

1. What did TCs learn through their Decoding project?

2. How did candidates connect Decoding to their future teaching practice?

3. How did candidates improve on an assessment of historical thinking skills and pedagogical content knowledge? 
Results indicate that the Decoding project had practical implications for disciplinary teaching. First, candidates learned to elicit students' disciplinary thinking -including misconceptions of disciplinary thinking. Second, Decoding made candidates contend with previously under-examined complexities of disciplinary thinking. This prepared candidates to better teach disciplinary thinking to secondary students. Finally, Decoding provided candidates with pedagogical frameworks for their own practice.

\section{THE DECODING THE DISCIPLINES PARADIGM}

The Decoding paradigm consists of an iterative seven stage framework (Middendorf and Pace 2004). Table 1 summarizes the seven stages of the framework, and a brief overview of the paradigm follows. For a more thorough treatment of the Decoding paradigm, including recent innovations, see Pace (2021).

Table 1. Decoding the Disciplines

\begin{tabular}{|l|l|}
\hline Stage & Description \\
\hline $\begin{array}{l}\text { Stage 1: What bottleneck } \\
\text { prevents learning? }\end{array}$ & $\begin{array}{l}\text { Instructors identify “bottlenecks"-places where students get stuck in } \\
\text { their thinking }\end{array}$ \\
\hline $\begin{array}{l}\text { Stage 2: How does an expert } \\
\text { do these things? }\end{array}$ & Instructors reflect on how experts work through the bottleneck \\
\hline $\begin{array}{l}\text { Stage 3: How can instructors } \\
\text { model thinking? }\end{array}$ & $\begin{array}{l}\text { Instructors explicitly model the steps experts take to work through the } \\
\text { bottleneck }\end{array}$ \\
\hline $\begin{array}{l}\text { Stage 4: How will students } \\
\text { practice? }\end{array}$ & $\begin{array}{l}\text { Instructors plan ways for students to practice doing the modeled steps } \\
\text { and receive feedback }\end{array}$ \\
\hline $\begin{array}{l}\text { Stage 5: What will motivate } \\
\text { students? }\end{array}$ & Instructors design ways to motivate the students \\
\hline $\begin{array}{l}\text { Stage 6: How well are } \\
\text { students mastering these } \\
\text { learning tasks? }\end{array}$ & Instructors plan for assessing learning \\
\hline $\begin{array}{l}\text { Stage 7: How can instructors } \\
\text { share resulting knowledge? }\end{array}$ & Instructors share what they learned with colleagues \\
\hline \multicolumn{2}{|l}{} \\
\hline
\end{tabular}

Decoding interviews comprise a key part of the process. These metacognitive interviews surface and make explicit experts' tacit thought. Decoding's framers originally developed Decoding interviews involving professors interviewing other professors across disciplines. However, Rouse et al. (2017) innovated the Decoding interview through including undergraduate students as interviewers and interviewees. Interviewing students and professors enabled researchers to compare experts and those developing expertise. Such comparisons enabled researchers to identify misconceptions or missteps in students' disciplinary knowledge.

Decoding uses the metaphor of a bottleneck to describe sticking points in students' disciplinary learning. As a traffic bottleneck halts vehicles, an intellectual bottleneck prevents students from developing more expert disciplinary thinking (Shopkow et al. 2013). In Decoding, instructors identify and address salient bottlenecks students face. Decoding interviews of students helps instructors more 
fully understand those bottlenecks. Decoding interviews of instructors help define how experts may think through that same bottleneck.

Experts rely on tacit disciplinary thinking: intuitive conclusions or ingrained heuristics developed through years of practice. Historians, for example, learned how to think historically through apprenticeship. Shopkow (2017) writes of her own apprenticeship:

As undergraduates, at best, we received procedural instructions without much explanation for their procedures. Most of us developed our understanding of historical thinking in graduate school, where we became involved in the situated cognition particular to historical thinking, underwent our true cognitive apprenticeships, and joined the historical community of practice (170).

Years of studying under historians ingrained in Shopkow (and other historians) the "unnatural act" (Wineburg 2001) of historical thinking that to a historian feels quite natural. To decode, experts must move this natural disciplinary thought from tacit to explicit. Decoding interviews with experts help interviewees make "explicit the hidden mental operations that are necessary to successfully complete the work in a course and to break these skills down into their component parts" (Pace 2017, 38). A Decoding interview with an expert primarily does not benefit the interviewer(s), but rather the interviewee; it forces expert thinkers, such as historians, to wrestle with putting tacit knowledge into words. Through making their tacit knowledge explicit, interviewees better prepare to explain those mental operations to students.

In this case study, TCs engaged most fully in Stages 1 and 2 of the Decoding paradigm, using Decoding interviews to both define the bottlenecks students face in evaluating sources for inclusion in a history paper and make more explicit the disciplinary thinking of historians encountering this same task. In their final Decoding reports, candidates addressed, but did not fully enact, subsequent stages of the Decoding paradigm through suggesting ways to improve instruction in the world history survey.

\section{DECODING AND K-12 EDUCATION}

A review of existing Decoding studies pertaining to K-12 teaching and teacher education reveals four capacities in which researchers have used Decoding. This review focuses particularly on the methodology, or the capacity in which researchers used Decoding to address K-12 teaching and teacher education.

Firstly, Decoding can inform teacher education practice; teacher educators can improve their practice through addressing bottlenecks TCs face in learning how to teach. Bottlenecks that impede learning skills necessary to teach others may include subject-specific disciplinary thinking bottlenecks; they can also include bottlenecks of pedagogical thinking. For example, Chistolini (2019a) used Decoding to address procedural and cognitive bottlenecks primary school TCs faced in a general pedagogy course. In the field of history education, Brown (2018) used Decoding to address secondary TCs' bottleneck of focusing on teacher performance rather than student thinking. Also in history education, Díaz and Shopkow (2017) used Decoding to identify disciplinary understanding (or lack thereof) as a potential bottleneck to effective lesson plan design for secondary TCs. Whether these bottlenecks had to do with specific disciplinary thinking skills or with more general pedagogical 
practices, teacher educators used Decoding to help make explicit for TCs the thinking necessary to work through bottlenecks in a formal teacher education course.

Decoding can also reveal expert thought in content-area disciplines-a second capacity where Decoding can inform K-12 teaching and teacher education. Disciplinary thinkers made more tangible their methods of thinking through Decoding; the results of these Decoding studies can provide TCs with examples of expert disciplinary thinking. In mathematics education, mathematicians Schultz and Lovin (2012) demonstrated their decoded disciplinary thinking to TCs as an example of moving from rote procedural knowledge to deeper content understanding in mathematics. Watching Schultz and Lovin decode their own mathematical thinking helped candidates develop mathematical knowledge for teaching (Ball, Thames, and Phelps, 2008). Likewise, in history education, Brown (2018) had secondary TCs read Pace's (2004) article that Decoded reading a text as a model of how historians read. TCs encountered a depiction of expert historical thinking through reading this study.

Thirdly, Decoding becomes a method of K-12 pedagogy. A limited number of studies used Decoding in elementary and secondary teaching. Some preliminary discussion of this emerged out of the Erasmus+ project "Decoding the Disciplines in European Institutions of Higher Education" (Chistolini $2019 b$ ). From this project, Bruno and Petrucci (2019) discuss applying Decoding methods to secondary schools, and Verkest (2019) describes how grade 5 teachers worked with Decoding to plan lessons that addressed students' bottlenecks of historical awareness and visual analysis. Cox's (2018) action-research study used Decoding in middle school history teaching. Cox designed scaffolds to address bottlenecks to reading primary sources identified in the research of Middendorf et al. (2007). Cox also interviewed focal students as they worked through this scaffolding to "decode" their emerging disciplinary thinking.

Cox's use of student interviews suggests the final capacity in which Decoding could play a role in K-12 teaching and teacher education: decoding the less-than-expert disciplinary thoughts of students. Students approach disciplines with varied prior conceptual understandings and misconceptions; expertise exists on a continuum from novice to expert (National Research Council 2000). Teachers, then, must elicit student thought, assess where on this continuum students think, and develop a proper response to move students toward more expert thought. However, many TCs struggle to elicit, assess, and attend to students' disciplinary thinking (Brown 2018; Monte-Sano and Budano 2013). If candidates learned the protocols of the Decoding interview not only to decode expert disciplinary thought, but also to decode student thought (Rouse et al. 2017), they gain a pedagogical tool for meeting this challenge.

This case study investigates the promise of Decoding in $\mathrm{K}-12$ teaching and teacher education in two of the four capacities above: as a method of K-12 pedagogy and a practice for eliciting students' lessthan-expert disciplinary thoughts. The specific research questions guiding this study include:

1. What did TCs learn through their Decoding project?

2. How did candidates connect Decoding to their future teaching practice?

3. How did candidates improve on an assessment of historical thinking skills and pedagogical content knowledge?

\section{RESEARCH CONTEXT}

Research took place in the course HIS 399: "The Teaching and Learning of History" at SUNY Cortland. A public college within the State University of New York (SUNY) system, SUNY Cortland is located in rural New York state. TCs take HIS 399 as part of a four-year undergraduate secondary social 
studies teaching program at SUNY Cortland-a professional sequence that involves training in general and disciplinary-specific pedagogy. In the United States, history and other academic disciplines such as political science, geography, economics, and sociology fall under the elementary and secondary school subject of the "social studies": the study of pursuits "whose subject matter relates directly to the organization and development of human society, and to man as a member of social groups" (Nelson 1994, 17).

In addition to the professional sequence at SUNY Cortland, TCs must also major in a social studies content area. All TCs in this study majored in history and had prior coursework in historical research and methodology, introductory history surveys, and upper-level history seminars. Most TCs begin their four-semester professional sequence for history teaching in the third year of college. HIS 399, taken in candidates' second semester of the sequence, focuses explicitly on SoTL in history. Candidates apply SoTL literature to assignments that replicate the work of teaching. For example, candidates practiced facilitating a disciplinary discussion, created a bibliography of appropriate teaching materials, and designed a pre- and post-assessment that measures secondary students' knowledge of historical facts, substantive concepts, and historical thinking skills (Lee, 2005). In my section of HIS 399, TCs also completed a small Decoding research project.

In the semester under study, HIS 399 started as a face-to-face course, meeting twice weekly for 50 minutes for discussion and other collaborative learning activities. However, in response to the COVID-19 pandemic, HIS 399 switched to distance learning at the semester's midpoint. While learning outcomes remained the same, some assignments and modes of instructional delivery shifted. However, the design of the Decoding project had only minor modifications, as videoconferencing adequately substituted for face-to-face interaction in this project.

Seventeen candidates enrolled in this section (of which 15 consented to include their data in this research). The majority of candidates identified as male, Caucasian, and traditional college students who began their undergraduate studies immediately after secondary school. At this point in their preparation, candidates had limited experiences observing students in the field. All had completed 25 hours of field work the previous semester. While this sample size captured nearly the whole population of the course, the examination of only one course means findings from the study must remain at the level of internal generalization. Further, TCs completed their Decoding project while living through a pandemic. Although the parameters of the project remained largely the same as presented at the beginning of the semester, TCs bore an additional burden of working through the pandemic's external anxieties and complications.

Instructors in all sections of HIS 399 attempted to accommodate those issues; accommodations at times led to less rigorous data collection in the research. As part of HIS 399, candidates drafted an assessment intended to measure secondary students' understandings of historical facts, substantive concepts, and skills. In the original course design, candidates would submit a draft of this assessment prior to the Decoding project and a revision after. However, HIS 399 instructors collectively made revisions optional in light of the pandemic. Most candidates chose not to revise the assessment, eliminating its utility as a measurement of the impact of the Decoding project.

\section{METHODOLOGY, DATA COLLECTION, AND ANALYSIS}

This article uses case study research methodology (Yin 2018) to examine TCs experiences using the Decoding paradigm. This methodology includes grounded theory (Charmaz 2006) to conduct 
document analysis and semi-structured interviews (Weiss 1994) to triangulate the results of this analysis. The study had prior approval of SUNY Cortland's institutional review board. Table 2 provides a timeline of the Decoding project and the data collection and analysis described below.

Table 2. Timeline of the Decoding project, data collection, and analysis

\begin{tabular}{|l|l|}
\hline Semester Week 1 & Pre-assessment \\
\hline Week 4 & $\begin{array}{l}\text { Presentation on Decoding, practice Decoding interviews, and } \\
\text { meeting with instructional library }\end{array}$ \\
\hline Weeks 5-11 & TCs continue to develop knowledge of source evaluation \\
\hline Week 12 & Interviews with undergraduate students \\
\hline Week 13 & TCs meet in small groups \\
\hline Week 14 & Decoding report submitted \\
\hline Week 15 & Post-assessment and course meeting \\
\hline May-June & Coding of data set \\
\hline June & Focal TC interviews \\
\hline
\end{tabular}

While all TCs engaged in all learning activities and submitted all assignments associated with HIS 399, only the assignments of those who had consented to participate in the study comprised the study's data set. In order to reduce any undue coercion to participate in the study, I explained that TCs could choose not to participate in the study and that I would only learn TCs' decisions to provide or withhold consent after finalization of course grades. Candidates indicated their consent on a digital form.

In Week 1, TCs completed a Pre-Assessment of Historical Thinking Skills and Pedagogical Content Knowledge (appendix C). This provided a baseline measurement and gave TCs a representation of the teaching practice of pre- and post-assessment. I modified a historical assessment of thinking and a corresponding rubric from "Beyond the Bubble" (Stanford History Education Group n.d.) to include additional questions that measured candidates' pedagogical content knowledge (Shulman 1987). Candidates spent no more than 20 minutes on the assessment.

In Week 4, I introduced TCs to the Decoding paradigm. Candidates received a handout (appendix A) adapted from Middendorf and Shopkow (2018) and Pace (2017). This handout covered interview procedures, suggested questions, and provided key points. In pairs, candidates practiced the Decoding interview, surfacing their own tacit thinking about selecting credible sources for history assignments. One candidate took the role of interviewer, a second the role of interviewee. After about 15 minutes, candidates reversed roles and repeated the interview. I circulated around the room and occasionally interjected with guidance for interviewers. A whole class debrief followed; candidates discussed difficulties of the interview and effective interview moves. In the next class session, SUNY Cortland's instructional services librarian provided a presentation on online source credibility. In that presentation, candidates learned and practiced the RADAR method of source evaluation (Mandalios 2013) and created a learning activity for secondary students using RADAR.

In subsequent class sessions, TCs continued to develop knowledge about source evaluation. Candidates read literature, including Bain (2005), Hynd (1999), and Wineburg (2001) and analyzed history-specific heuristics for reading and evaluating sources. In particular, candidates discussed Wineburg's (2010) list of heuristics: sourcing, contextualization, close reading, using background 
knowledge, reading the silences, and corroborating. In order to conceptualize such heuristic lists as instructional, rather than dogmatic, candidates also briefly considered Baron's (2012) alternate list of historical thinking heuristics.

In Week 12, TCs interviewed a student from a world history survey course I also taught that semester. COVID-19 slightly changed the design for this aspect of the Decoding project. Originally, interviewees would come from among the population of first-year students in history survey courses at SUNY Cortland. However, with in-person recruitment no longer possible, the research project shifted to only include students (of all grades) from my world history survey section. This shift meant that TCs only saw students who shared the same instructor and saw a wider variety of grades than only first-year undergraduates. However, since students took this course to fulfill a general education requirement, most had not taken another history course since high school. Additionally, since all students came from the same section, TCs interviewed students about a common assignment: an analytical paper comparing two primary sources. Candidates received a copy of the assignment prompt and grading rubric for this analytical paper.

In Week 12, candidates also received instructions for their Decoding report (appendix B), including a rubric based on evaluative rubrics from the National Council for the Social Studies National Standards for the Preparation of Social Studies Teachers (National Council for the Social Studies Task Force on Teacher Education Standards 2018) and the edTPA, a performance-based, subject-specific assessment of teaching (Stanford Center for Assessment, Learning, and Equity 2019).

TCs interviewed their assigned student via videoconferencing, asking students the question: "How do you select credible sources for your history assignments?" Candidates took detailed notes during the interview and wrote a reflective memorandum capturing their initial thoughts at the interview's conclusion. Due to logistical issues, three candidates did not complete their own Decoding interviews, and instead utilized peers' interview observations and memoranda.

In Week 13, TCs met virtually in a research group of four to five members to examine a "class" of students. Each class included research group members' interview notes and reflective memoranda. Additionally, research groups that contained less than five candidates or that included candidates unable to complete their own interview included additional interview notes and reflective memoranda from candidates in a different research group. This ensured that every research group, regardless of size, had data from five undergraduate students. Candidates read through their assigned class data before their research group meeting.

In the meeting, TCs examined patterns of student thought: What did students do well? What might their instructor need to address? How should he respond to findings from Decoding interviews? Candidates shared annotations on their class data set through Perusall, a social e-reader platform that allows for collaborative annotation, and discussed findings over videoconferencing.

After meeting in research groups, each TC prepared an individual final report for the Decoding project, submitted in Week 14. This report had three sections. First, candidates analyzed students' disciplinary thought, noting strengths and bottlenecks. Second, candidates planned next teaching steps, identified pedagogical activities that could help students overcome bottlenecks, and cited scholarly literature to justify those activities. Finally, candidates wrote a reflection on their learning from the project, noting how it might connect to their future teaching practice.

In Week 15, TCs completed the post-assessment of Historical Thinking Skills and Pedagogical Content Knowledge and submitted course evaluations. In addition to the university's standard course 
teaching evaluations, TCs also completed an additional anonymous feedback form. This form included a prompt about the Decoding project: "What is your reaction to our Decoding the Disciplines project? What aspects of the project were valuable to you as a teacher? What aspects of the project were not valuable or need to be changed? Should I continue to do this type of activity with teacher candidates? Why or why not?" Eleven candidates responded to this question.

After submitting course grades, I assembled a data set from consenting TCs. This data set included results of the pre- and post-assessments, Perusall comments on interview data, Decoding project final reports, and responses on anonymous end-of-course feedback. To preserve anonymity, only a random three-digit number identified candidates in the data set.

Open coding (Emerson, Fretz, and Shaw 2011) to examine emergent patterns followed assembly of the data set. The findings generated through open coding led to the development of focused coding (Charmaz 2006) categories and sub-categories. Table 3 lists focused coding categories, subcategories, and quantitative counts of focused coding categories present in Decoding reports.

\section{Table 3. Focused coding results}

\begin{tabular}{|l|l|r|}
\hline Focused coding category & Sub-category & $\begin{array}{l}\text { Number of Decoding reports }(\mathrm{n}=15) \\
\text { addressing the sub-category }\end{array}$ \\
\hline Student's knowledge & Variations in student thought & $7(46.7 \%)$ \\
\cline { 2 - 3 } & Folkways & $13(86.7 \%)$ \\
\cline { 2 - 3 } & Bottlenecks & $12(80.0 \%)$ \\
\cline { 2 - 3 } & Vocabulary & $5(33.3 \%)$ \\
\cline { 2 - 3 } & What the student does well & $7(80.0 \%)$ \\
\hline The Decoding process & $\begin{array}{l}\text { Using Decoding interviews in } \\
\text { teaching }\end{array}$ & $76.7 \%)$ \\
\cline { 2 - 3 } & Eliciting student thought & $5(33.3 \%)$ \\
\cline { 2 - 3 } & Assessment & $2(13.3 \%)$ \\
\cline { 2 - 3 } & $\begin{array}{l}\text { What needs emphasis when } \\
\text { teaching historical thinking }\end{array}$ & $12(80.0 \%)$ \\
\hline Self-knowledge & How TCs find credible sources & $7(26.7 \%)$ \\
\cline { 2 - 3 } & $\begin{array}{l}\text { How TCs learned to find } \\
\text { credible sources }\end{array}$ & $8(53.7 \%)$ \\
\cline { 2 - 3 } & $\begin{array}{l}\text { Gaps between student thought } \\
\text { and TCs' thought }\end{array}$ & $8 \%(53 \%)$ \\
\hline
\end{tabular}

Findings from focused coding informed a script for semi-structured interviews (Weiss 1994) with focal TCs. I selected four focal candidates out of the 13 candidates willing to participate in followup interviews. In order to incorporate a diversity of perspectives on the Decoding project, these four focal candidates included three men and a woman, a mixture of traditional and non-traditional college students, and candidates with a range of final course grades and grades on the Decoding report. Interviews helped triangulate findings from focused coding, probe deeper into tentative findings, and give a small measure of candidates' retention of their learning from the Decoding project. 


\section{FINDINGS}

\section{Delving into the minds of students}

Through Decoding, TCs sharpened their ability to create a Theory of Mind for students. Cognitive psychologists describe Theory of Mind as:

Our ability to explain behavior in terms of underlying thoughts, feelings, desires, and intentions. We attribute states of mind to ourselves and others all the time. Our attributions are frequently incorrect, but, still, making them is the default way by which we construct and navigate our social environment (Zunshine 2010, 117).

A more attuned Theory of Mind improves a teacher's ability to diagnose students' misconceptions and support students' continued learning. Because Decoding interviews forced candidates to elicit students' thinking, it provided more data for candidates to incorporate into their Theory of Mind for students.

To develop a Theory of Mind for students, TCs first had to recognize differences between students' thinking and their own. In eight Decoding reports, candidates mentioned explicitly the gap between their disciplinary thought and that of interviewed students. Seeing others' thinking helped candidates realize that, while they had already internalized ways of historical thinking after additional study of history, their students had not. TC490 mentioned this several times, writing "[f]rom the interviews I learned that my knowledge regarding the disciplines in history is tacit for me, but other students may not think similarly," and later, "[f] or me, it seems logical that sources written from varying perspectives may be different. As I have learned, that is not always clear for students." New teachers must learn this important lesson: that what seems natural or obvious to them (after much study in the discipline) might not also seem natural or obvious for students.

TCs observed gaps between their more expert and students' more novice historical thinking. But they also noticed variety across students' thinking. Seven candidates wrote about this variation in students. TC514 wrote "[a]s a teacher, I learned that all students have a variety of skills within the discipline of history." TC273 created a spectrum, noting "some students had a greater understanding and demonstration of the groundworks of what makes up historical disciplinary thought in their work while others showed a more basic understanding, and some had barely any idea at all." New teachers must also realize this diversity in student thinking; they must create not a Theory of the Mind, but rather Theories of the Minds for many different students. However, in a case study, Dack and Triplett (2020) found that new teachers often fail to see meaningful differences in the thinking of students. This failure impedes teachers from realizing the necessity to enact meaningfully differentiated instruction. When students have meaningful differences in their cognition, they need differentiated instruction tailored to their different learning needs (Tomlinson and Moon 2013). Decoding made TCs contend meaningfully with differences in students' thinking and create separate Theories of Minds for each of their students, enabling them to practice responding instructionally to those differences.

\section{Bottlenecks}

Once TCs realized differences in their students' disciplinary thoughts, they could then identify potential bottlenecks impeding students' disciplinary thinking. All candidates wrote about bottlenecks, although some lacked clarity in describing them. Twelve candidates included clearly identified bottlenecks in their Decoding reports — an expectation of the assignment and a crucial part of the 
Decoding paradigm. Candidates did vary, however, in the types of bottlenecks identified. These bottlenecks fell into three varieties: overly general bottlenecks, specific but surface-level bottlenecks, and bottlenecks that contended with deep epistemological concerns of the discipline.

Two TCs identified bottlenecks that fell into the first variety: overly general. Such bottlenecks imprecisely described what impeded students, and this lack of precision limited candidates' abilities to design targeted interventions guiding students through bottlenecks. TC143 wrote "the student does not know how to find a credible source," and TC273 wrote "one area of bottlenecking seen in multiple cases from the students was a lack in the practice of standard historical research discipline/methods." These candidates recognized issues with students' disciplinary thought, but further deconstructed bottlenecks would provide more specific reasons for students' difficulties.

Six TCs identified bottlenecks of the second variety: specific but surface-level bottlenecks that enabled actionable responses. These included bottlenecks like failing to consider a source's author, historical context, or credibility of a digital publisher. Unlike the overly general bottlenecks of the first variety, such discrete bottlenecks better prepared candidates to create actionable teaching responses to address them.

Four TCs identified bottlenecks that went beyond surface-level to consider more closely the epistemological underpinnings of the discipline of history. Although they also noted student missteps similar to those in the second bottleneck variety, these candidates delved into why historians thought in a certain way and why students might not engage in similar cognition. Some candidates indicated how historians consider perspectives and biases at play in evaluating sources, but students did not consider how an author's perspective factors into source evaluation. TC580, for example, wrote:

The major bottleneck that I see is that students will fail to see the biases that exist in texts and instead see texts as a source of authority to retrieve facts from. Furthermore, students will see history simply as retrieval of facts rather than inquiry and evidence-based interpretations.

Such epistemological bottlenecks parallel the disciplinary misconceptions Bain $(2000,2006)$ described in his secondary students. In another example, TC137 noticed students' tendency to first develop a claim and then find sources to support that claim, without properly considering reliability of the source. TC137 wrote "[s]tudents... just see if the primary source has information that will help their claim even if the source was written well after the event they are writing about." In addition to failing to consider source reliability, students' selective use of evidence to support an a priori claim, rather than developing an a posteriori claim from evidence, runs counter to good historical thought. Candidates who identified this third variety of bottlenecks had gone the furthest in decoding the disciplinary thoughts of experts and applying that decoded disciplinary thought toward identifying cognitive missteps in students.

\section{Folkways}

TCs also noted "folkways" students employed to identify sources for a history paper. Although these folkways did not necessarily lead to poor history sources, students' underlying assumptions of these folkways, if not addressed, could prove troublesome for students' development of historical thinking skills. Candidates' reports analyzed the assumptions behind three common folkways: searching with Google, relying on domain endings, and unquestioning trust in the professor. 
Seven TCs mentioned students' use of the search engine Google and its potential problems. Google's search database and guiding algorithms can saturate students with too many sources (including sources of questionable reliability) and exclude quality sources (Kelly 2013). As TC105 noted:

While Google can be extremely helpful in finding sources, it can also cause a hindrance, as it could lead to unreliable sources... Though [students] were able to use Google to find sources, they do not have the skills to determine if those sources are dependable or not.

Despite this, students preferred Google to the university library's database. TC374 wrote that students "felt that they had a better chance at finding a source for school use" through Google than through the library search engine.

Six TCs identified the student folkway of using domain endings as a heuristic to evaluate digital sources. Many students focused on results from .edu, .gov, or .org web domains, avoiding .com, .net, and other domain endings. As TC786 explains: "Student A only looks for .edu or .gov websites. Student A does this because, 'Not any random person can make these sites to put false info out.' This thinking could lead to some serious issues in their work." While regulations constrain access to .edu, .gov, or .org domains, students can place too much trust in the authority such domain endings convey. An overuse of the domain ending folkway could lead students to both reject useful sources and include non-credible sources based solely on their domain endings.

Students displayed a similar over-confidence in the authority of their professor and textbooks. Eight TCs mentioned the unquestioning trust students placed in their instructor and the provided texts for the course - a folkway Bain (2006) also encountered with his secondary students. TC580 wrote that, "[i]n reflecting on these interviews, my assessment is that this particular set of HIS 100 students confirms Sam Wineburg's assertion that adolescent students see teachers and textbooks as authority and education in history as the gathering of information." TC430 mentioned how students "responded comfortably" to just trusting their professor and the textbook. On the one hand, this reveals a heartening trust in my credibility. But on the other hand, such blind trust in authority without critical thinking supports, as TC241 wrote, "a fairly bad habit... 'if it is in the textbook, it must be correct' which we as historians know that is not true." Critical reading, including critical reading of instructors and provided texts, comprise an essential element of historical thinking. Students may still choose to place their trust in an authoritative figure's choice of sources, but good history instruction must help students develop criteria for why they trust such sources that goes beyond mere passive acceptance (Bain 2006).

Through Decoding, TCs gained familiarity with folkways students employ, but more importantly, candidates also surfaced assumptions and misassumptions students held about those folkways.

\section{The power of words}

Bain (2005) highlights the importance of adopting discipline-specific linguistic devices as "mindtools" (Jonassen 2000): cognitive tools that assist students with disciplinary thinking. As Bain demonstrated, history-specific vocabulary helps "sharpen students' thinking about history in ways not possible without that vocabulary” (203). Indeed, Wineburg's (2010) reification of discrete skills within historical thinking provides a vocabulary for learning disciplinary thought. Such vocabulary mindtools can support students' development of historical thinking. 
Five TCs wrote about disciplinary vocabulary in their Decoding reports. Candidates identified words students did (or did not) use as indicative of students' (mis)understanding and explicit knowledge. Candidates noted where students' lack of specific vocabulary prevented them from making disciplinary thinking explicit. TC241 reflected on how two specific mindtools "history-as-event" and "history-as-account" (Bain 2005) would help prevent students from conflating historical events and historical accounts: "These students seem to be lacking in understanding that history as an account verses history as an event are two different things." TC430 reflected on their own learning after interviewing a student who did not know the word corroboration: "One student reported not knowing what corroboration meant and I am sure she would not be the first or last to admit that. I do not remember learning it until college either." Lacking definitions of these words meant students lacked control over their disciplinary thinking.

At other times, candidates noticed when students used disciplinary vocabulary without understanding the word's definition in context. TC241 saw this with the word bias:

[Students] often threw around the word bias without truly understanding the historical definition of bias. As historians we prefer to see these sources as perspectives and not strictly bias, because bias assumes that the writer is purposefully changing the story for some gain.

This misdefinition of disciplinary-specific words led to missteps in disciplinary thinking.

Candidates also encountered students who could make their historical thinking explicit with disciplinary vocabulary. TC786 wrote about a student who "understood contextualization, and even used the word to describe using background information in their paper." TC786 saw the linkage between understanding the word contextualization and performing that skill. This and other vocabulary mindtools sharpened students' disciplinary thinking.

Two TCs suggested explicitly introducing vocabulary to help students progress in their thinking. TC289 planned to provide students with "a language support with appropriate sourcing vocabulary so that students have an idea on what they should be doing." TC430 had an extensive list of vocabulary to help students overcome their bottlenecks:

I think another plan for overcoming the bottlenecks they had would be to review the vocabulary that would be used in their prompts and instructions so they know exactly what they are being asked of. Also, the vocabulary of the strategies that will encourage not just the use of multiple credible sources but also how to connect them to each other and not just to their argument would activate their higher order thinking as well as strengthening their writing. The vocabulary the students would need to know and understand would be words such as contextualization, sourcing, corroborating.

Through interviews, candidates realized the power certain words hold as mindtools and planned to introduce such vocabulary to their own students.

\section{Recognizing Decoding as a K-12 teaching practice}

Many candidates saw parallels between Decoding research and teaching practices. Seven wrote about how they might incorporate Decoding interviews into teaching secondary students through 
interviewing their own students or incorporating Decoding interview questions into classroom discussion. Several candidates found that conducting Decoding interviews helped them facilitate meaningful classroom discussion. TC289 wrote:

It was very helpful in learning how to approach students with distinct questions without revealing the answer. One of my difficulties is jumping to the answer if my students cannot provide one or there is a long pause. This though forced me to work on that and how I shape my questions in order to try and get students to critically think and not give up.

Candidates recognized that, done well, both Decoding interviews and discussion facilitation use probing questions to externalize and examine student thought.

Five TCs wrote generally about how the Decoding project reinforced the importance of eliciting student thought. TC105 wrote that the project provided practice analyzing the thinking of students: " [b] eing able to analyze how someone thinks is something that takes effort and practice, much like learning how thinking historically takes effort and practice. Learning how to unlock this skill in college will get us ready for doing it in the real professional world, with our students." TC786 commented that:

Grading work can only take a teacher's understanding of the students' work so far. You can follow a pattern of mistakes and errors, but that is not going to tell a teacher why a student is making those mistakes. Sometimes, you have to ask the student what they are struggling with or what you are not making clear as a teacher.

For these candidates, their Decoding experience revealed the importance of understanding student thought and provided practices for eliciting that thought.

\section{Assessment}

Despite the focus of HIS 399 on disciplinary assessment design, only two TCs mentioned assessment in Decoding reports. TC323 wrote that Decoding indicated a need to "measure my students' abilities" early to inform teaching. TC374 wrote that the experience "taught me how to properly assess prior knowledge of students and how to further use those answers to design lessons and activities." While no other candidates wrote about assessment, all four focal candidates mentioned assessment in follow-up interviews as something they learned from Decoding. This suggests perhaps more candidates made tacit, if not explicit, connections to assessment through their Decoding project. Future iterations of this project will benefit through making more apparent connections between Decoding and assessment.

\section{Self-reflection on disciplinary thought}

In this project, TCs decoded not only the thinking of interviewed students, but also their own cognition. Four candidates wrote how the project sharpened their disciplinary thinking. TC143 found: "Not only do I realize what mistakes or questionable methods the students are using I realized my own mistakes that I have been doing in my research process and in my writing." Likewise, TC430 found conducting Decoding research made them "a more confident historian." Unpacking their tacit knowledge led candidates to deepen their expertise, improving how they evaluated sources and avoiding 
the mistakes fellow college students exhibited. Additional candidates reflected on their own growth over time. Many recognized, like TC289, that "I was in [interviewed students'] shoes only three years ago," and college students either "weren't properly taught how to handle sources in high school," or "it was not done well enough to stick." Candidates' reflection on their own learning helped identify experiences that made learning "stick": presentations from the college library, readings, and learning activities from prior coursework. Most importantly, candidates thought about ways to adapt those learning experiences so that the historical skill of sourcing could also "stick" with future students.

Instructors in higher education typically hold high levels of expertise in their field; they actively research in their discipline and so possess great deals of tacit disciplinary expertise that needs decoding to teach to students. K-12 teachers, on the other hand, occupy a different location on the spectrum from novice to expert: not as expert as researchers in the discipline, but more expert than the students they teach. This makes K-12 teachers' work with decoding slightly different than that of disciplinary experts; because of their position on the spectrum, K-12 teachers can further develop disciplinary expertise through decoding expert thought and further develop pedagogical expertise through decoding students' more novice thinking. Both actions deepen TCs pedagogical content knowledge (Shulman 1987) — the specialized knowledge that allows teachers to represent or translate disciplinary knowledge in ways that allow student learning.

\section{PRE- AND POST-ASSESSMENT PERFORMANCE}

Figures 1-3 summarize candidates' performance on the three questions of the pre- and postassessments of historical thinking skills and pedagogical content knowledge. Appendix $\mathrm{C}$ contains the assessment and the rubric used to evaluate basic, emergent, and proficient responses.

\section{Figure 1. Assessment of historical thinking skills and pedagogical content knowledge, question 1}

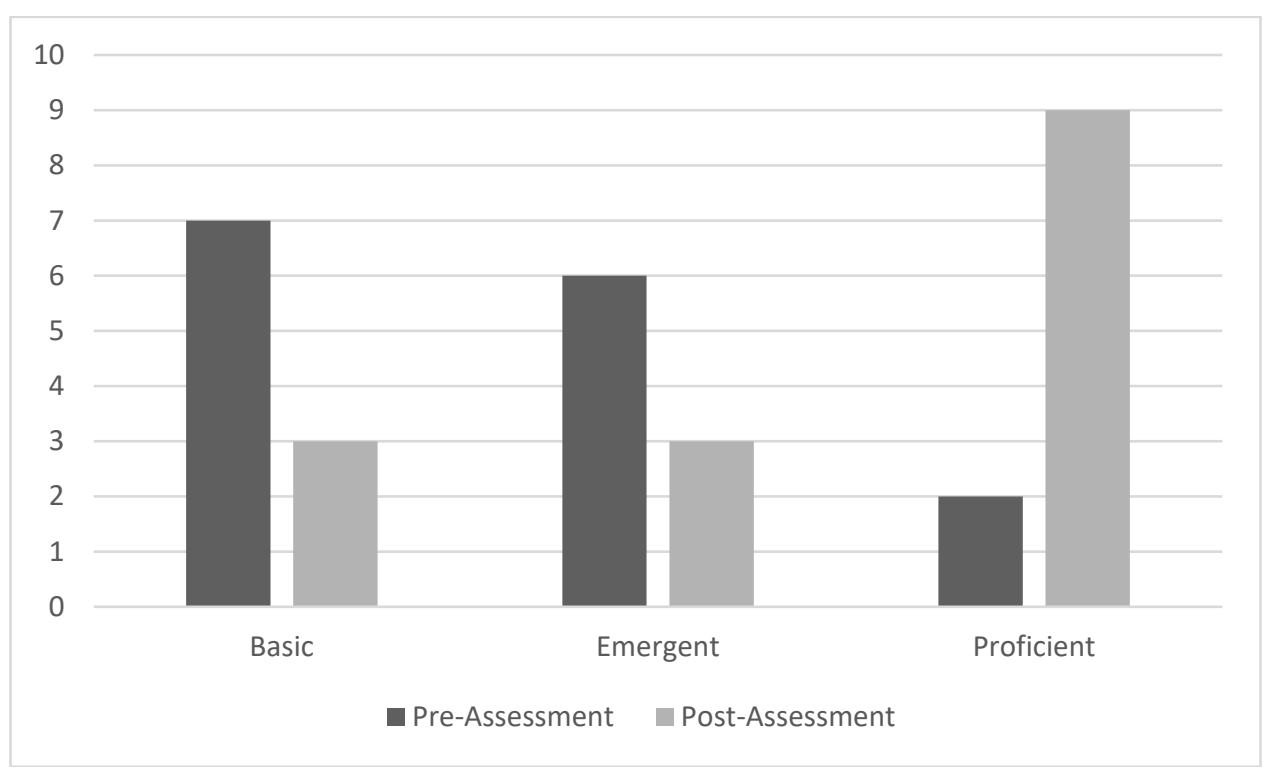

Question 1 measured candidates' ability to identify substantive concepts or second-order skills (Lee 2005) they could teach using the image "Storming the Encampment at Gadan-Ola." Candidates greatly improved on Question 1; seven more candidates earned a score of proficient on the post- 
assessment than on the pre-assessment. Six candidates identified contextualizing as a skill they could teach with the image; five candidates identified sourcing. These two skills most closely connected to the topic of their Decoding interviews.

Figure 2. Assessment of historical thinking skills and pedagogical content knowledge, question 2

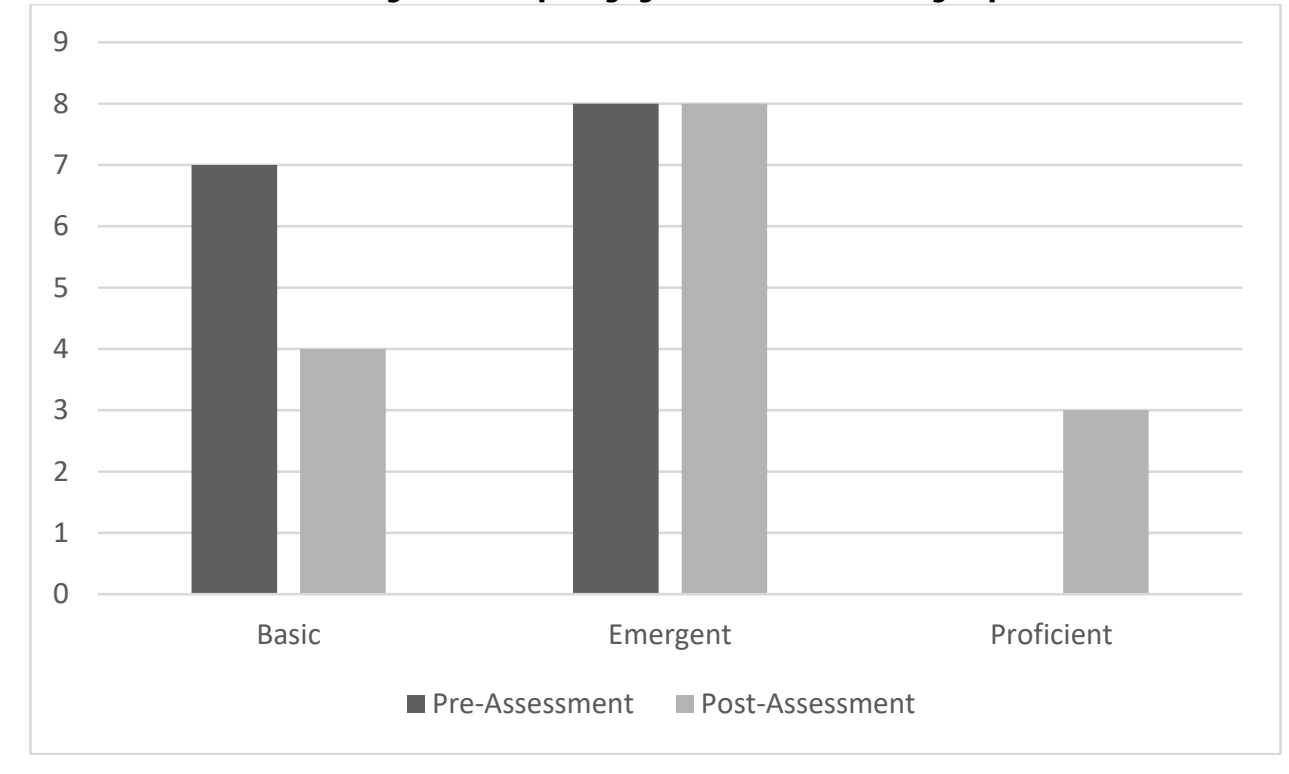

Question 2 measured TCs' ability to plan for teaching substantive concepts or skills with the image. Candidate performance improved on Question 2; three more candidates earned a score of proficient and three less earned a score of basic on the post-assessment.

\section{Figure 3. Assessment of historical thinking skills and pedagogical content knowledge, question 3}

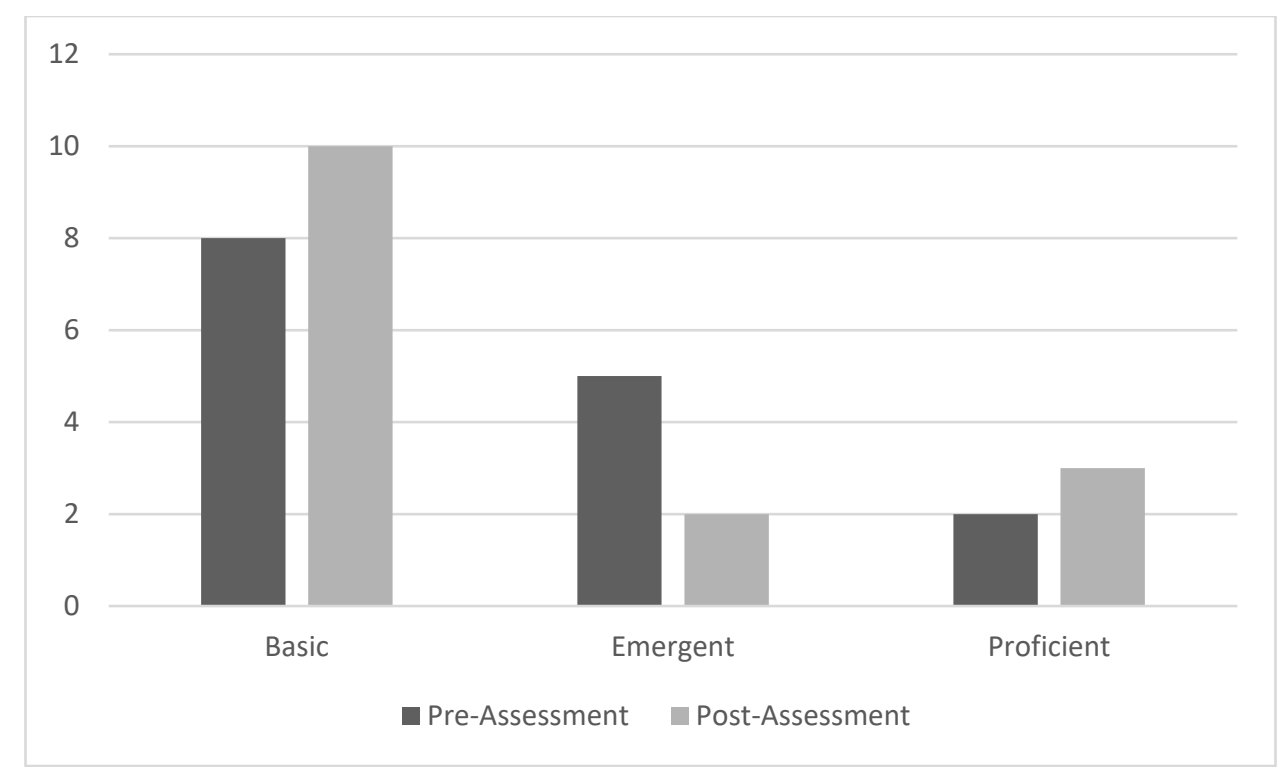


Finally, Question 3 measured TCs' ability to evaluate the credibility and reliability of a source. Although proficient responses increased on the post-assessment, basic responses did also. Analysis of the responses of candidates who regressed on the post-assessment, however, indicated a misreading of the prompt. Those candidates ignored the reliability of the print itself, and instead wrote on the reliability of the digital database that housed this print—-the World Digital Library (2014). ${ }^{1}$ Although the prompt did not ask about the digital database, the course's focus on reliable digital archives may have led to understandable confusion for some candidates. Future iterations of the pre- and post-assessment have an additional question to distinguish between reliability of the print itself and reliability of its digital database.

\section{TEACHER CANDIDATE RESPONSES TO DECODING}

TCs responded positively to their Decoding project. Eleven candidates provided responses to anonymous end-of-course feedback. Of those responses, only one had a comment categorized as negative; this candidate wrote that the project "would have been more clear and effective on campus," referring to the transmission to remote learning. Remaining candidate responses all gave positive feedback. Five responses explicitly stated that I should continue doing Decoding projects with future cohorts of TCs. One comment, in particular, captured the range of positive responses in this anonymous feedback:

\section{Ifound much value in the Decoding the Disciplines project. It showed me that future classes of mine may show strong trends identifying where students both succeed and struggle as historians. It showed me that I could implement projects like this in my own classes to see where students struggle with research, then use that information to modify lessons. You should definitely continue doing this activity.}

During a time when COVID-19 canceled early field experiences, candidates enjoyed the authentic practice and "hands on" experience of eliciting student thought. Candidates valued such authentic practice-based learning.

\section{CONCLUSION}

Through Decoding interviews, TCs learned practices for eliciting students' disciplinary thoughts. This exposed candidates to common problems students face in evaluating historical sources, including bottlenecks, misconceptions, and folkways. Contending with student thought also forced candidates to more explicitly contend with their own disciplinary thinking; some found such close examination improved their own disciplinary thinking. Decoding students' thoughts around evaluating historical sources gave candidates suggestions for teaching that topic to high school students. For many candidates, the Decoding paradigm provided a teaching practice useful for decoding and teaching other aspects of disciplinary thought. In summary, this study demonstrates the positive effects of adapting Decoding as a method of $\mathrm{K}-12$ teacher preparation.

The data examined, however, does not reveal how well the practices of Decoding transferred into TCs' future work as teachers. Although candidates reflected on how they might incorporate Decoding into their practice, this remains hypothetical and self-reported. Further study would determine whether candidates actually transferred the skills of Decoding into future practice. 
Pace (2017) argued that Decoding the Disciplines could provide a language of teaching and learning to address the chasm between secondary and higher education. For the TCs of this study, practicing Decoding in the context of higher education not only revealed this chasm, but provided a mechanism for bridging it. As TC274 wrote:

What I learned from analyzing the Decoding the Disciplines interviews is that coming into college, not every student is well trained in the disciplines of historical thinking/research and that is understandable, but this lack in training can be improved starting in the high school classroom.

Learning Decoding has given TC274 and others the tools for training high school students in historical thinking.

But there exists another chasm that Decoding as a pedagogy of teacher education can help bridge: the chasm between instructor and learner. Involving students in Decoding, as interviewees or as co-investigators, provides an important update to the Decoding paradigm (Pace 2021). In this “Decoding 2.0," instructors better see students not as blank slates, but as thinking individuals who can play a valuable role in co-constructing the learning environment. Through honoring students as emergent disciplinary thinkers, candidates could better attend to developing that disciplinary thought.

\section{ACKNOWLEDGMENTS}

I thank David Pace, Leslie Cameron, and Holly Pelnar for valuable collaboration uniting the two SoTL strands of Decoding the Disciplines and Students-as-Partners. I am also grateful for the support of a classroom research grant from the Institute for College Teaching at SUNY Cortland. Finally, I am most thankful for my students and their enthusiastic participation in this research project.

Jared McBrady is an Assistant Professor of History and Coordinator of the Adolescence Education Social Studies program at SUNY Cortland (USA). His teaching and research focuses on the preparation of K-16 history teachers.

\section{NOTES}

1. As an example, one candidate wrote: "I went to the World Digital Library website. I found that the site is run by the Library of Congress, which is a well renowned source for accurate information...." Although this does not assess the reliability of the print, it does accurately assess the digital resource that houses the print.

\section{ETHICS}

Research was approved through the SUNY Cortland institutional review board.

\section{REFERENCES}

Bain, Robert B. 2000. "Into the Breach: Using Research and Theory to Shape History Instruction. In Knowing, Teaching, and Learning History: National and International Perspectives, edited by Peter N. Stearns, Peter Seixas and Sam Wineburg, 331-52. New York: New York University Press.

Bain, Robert B. 2005. "'They Thought the World was Flat?' Applying the Principles of How People Learn in Teaching High School History." In How Students Learn: History in the Classroom, edited by M. Suzanne Donovan and John D. Bransford, 179-214. Washington, DC: National Academies Press. 
Bain, Robert B. 2006. "Rounding Up Unusual Suspects: Facing the Authority Hidden in the History Classroom." Teachers College Record 108, no. 10: 2080-114.

Ball, Deborah Loewenberg, Mark Hoover Thames, and Geoffrey Phelps. 2008. "Content Knowledge for Teaching: What Makes It Special?" Journal of Teacher Education 59, no. 5: 389-408. https://doi.org/10.1177\%2F0022487108324554.

Baron, Christine. 2012. "Understanding Historical Thinking at Historic Sites." Journal of Educational Psychology 104, no. 3: 833-47. https://psycnet.apa.org/doi/10.1037/a0027476.

Brown, Sarah Drake. 2018. "Assessing While Learning: Teacher Candidates in the History Classroom." Social Studies Education Review 7, no. 3: 22-41.

Bruno, Patrizia, and Nadia Petrucci. 2019. "Decoding the Disciplines. Applying the Methodology to High School." In Decoding the Disciplines in European Institutions of Higher Education: International and Interdisciplinary Approach to Teaching and Learning, edited by Sandra Chistolini, 44-45. Milan, Italy: FrancoAngeli.

Charmaz, Kathy. 2006. Constructing Grounded Theory: A Practical Guide Through Qualitative Analysis. Los Angeles: Sage.

Chistolini, Sandra. 2019a. "Decoding the Disciplines in Pedagogy and Further Development of the Methodology." In Decoding the Disciplines in European Institutions of Higher Education: International and Interdisciplinary Approach to Teaching and Learning, edited by Sandra Chistolini, 34-43. Milan, Italy: FrancoAngeli.

Chistolini, Sandra, ed. 2019b. Decoding the Disciplines in European Institutions of Higher Education: International and Interdisciplinary Approach to Teaching and Learning. Milan, Italy: FrancoAngeli.

Cox, William R. 2018. "The Impact of Scaffolding on the Historical Thinking Skills of Middle School Students." EdD diss., University of South Carolina.

Dack, Hilary, and Nicholas Triplett. 2020. “Novice Social Studies Teachers' Implementation of Differentiation: A Longitudinal Multicase Study." Theory \& Research in Social Education 48, no. 1:32-73. https://doi.org/10.1080/00933104.2019.1640149.

Díaz, Arlene J., and Leah Shopkow. 2017. "A Tale of Two Thresholds." Practice and Evidence of the Scholarship of Teaching and Learning in Higher Education 12, no. 2: 229-48.

Emerson, Robert M., Rachel I. Fretz, and Linda L. Shaw. 2011. Writing Ethnographic Fieldnotes. Chicago: University of Chicago Press.

Hynd, Cynthia R. 1999. "Teaching Students to Think Critically Using Multiple Texts in History." Journal of Adolescent \& Adult Literacy 42, no. 6: 428-36.

Jonassen, David H. 2000. Computers as Mindtools for Schools: Engaging Critical Thinking. Upper Saddle River, NJ: Merrill.

Kelly, T. Mills. 2013. Teaching History in the Digital Age. Ann Arbor: University of Michigan Press. http://dx.doi.org/10.3998/dh.12146032.0001.001.

Lee, Peter J. 2005. "Putting Principles into Practice: Understanding History." In How Students Learn: History in the Classroom, edited by M. Suzanne Donovan and John D. Bransford, 31-77. Washington, DC: National Academies Press.

Mandalios, Jane. 2013. "RADAR: An Approach for Helping Students Evaluate Internet Sources." Journal of Information Science 39, no. 4: 470-78. https://doi.org/10.1177\%2F0165551513478889.

Middendorf, Joan, and David Pace. 2004. "Decoding the Disciplines: A Model for Helping Students Learn Disciplinary Ways of Thinking." In Decoding the Disciplines: Helping Students Learn Disciplinary Ways of Thinking, edited by David Pace \& Joan Middendorf, 1-12. San Francisco: Jossey-Bass.

Middendorf, Joan, and Leah Shopkow, L. 2018. Overcoming Student Learning Bottlenecks: Decode Your Disciplinary Critical Thinking. Sterling, VA: Stylus.

Middendorf, Joan, David Pace, Leah Shopkow, and Arlene Díaz. 2007. "Making Thinking Explicit: Decoding History Teaching." The National Teaching and Learning Forum 16, no. 2: 1-4.

Monte-Sano, Chauncey, and Christopher Budano. 2013. "Developing and Enacting Pedagogical Content Knowledge for Teaching History: An Exploration of Two Novice Teachers' Growth Over Three Years. Journal of the Learning Sciences 22, no. 2: 171-211. https://doi.org/10.1080/10508406.2012.742016.

National Council for the Social Studies Task Force on Teacher Education Standards. 2018. National Council for the Social Studies National Standards for the Preparation of Social Studies Teachers. 
National Research Council. 2000. How People Learn: Brain, Mind, Experience, and School: Expanded Edition. Washington, DC: The National Academies Press. https://doi.org/10.17226/9853.

Nelson, Murray R., ed. 1994. The Social Studies in Secondary Education: A Reprint of the Seminal 1916 Report with Annotations and Commentaries. Bloomington, IN: ERIC Clearinghouse for Social Studies/Social Science Education.

Pace, David. 2004. "Decoding the Reading of History: An Example of the Process." In Decoding the Disciplines: Helping Students Learn Disciplinary Ways of Thinking, edited by David Pace and Joan Middendorf, 13-22. San Francisco: Jossey-Bass.

Pace, David. 2017. The Decoding the Disciplines Paradigm: Seven Steps to Increasing Student Learning. Bloomington, IN: Indiana University Press.

Pace, David. 2021. "Beyond Decoding the Disciplines 1.0: New Directions for the Paradigm." Teaching \& Learning Inquiry 9, no. 2: 1-27. https://doi.org/10.20343/teachlearninqu.9.2.3.

Pace, David, and Joan Middendorf, eds. 2004. In Decoding the Disciplines: Helping Students Learn Disciplinary Ways of Thinking. San Francisco: Jossey-Bass.

Rouse, Mary, Julie Phillips, Rachel Mehaffey, Susannah McGowan, and Peter Felten. 2017. "Decoding and Disclosure in Students-as-Partners Research: A Case Study of the Political Science Literature Review." International Journal for Students as Partners 1, no. 1: 1-14. https://doi.org/10.15173/ijsap.v1i1.3061.

Schultz, Kyle T., and LouAnn Lovin. 2012. "Examining Mathematics Teachers' Disciplinary Thinking." The Mathematics Educator 21, no. 2: 2-10.

Shopkow, Leah. 2017. "How Many Sources Do I Need?" The History Teacher 50, no. 2: 169-200.

Shopkow, Leah, Arlene Díaz, Joan Middendorf, and David Pace. 2013. "From Bottlenecks to Epistemology in History: Changing the Conversation about the Teaching of History in Colleges and Universities." In Changing the Conversation about Higher Education, edited by Robert J. Thompson, Jr., 15-28. New York: Rowman \& Littlefield Publishing.

Shulman, Lee S. 1987. "Knowledge and Teaching: Foundations of the New Reform." Harvard Educational Review 57, no. 1:1-22.

Stanford Center for Assessment, Learning, and Equity. 2019. edTPA Secondary History/Social Studies Assessment Handbook.

Stanford History Education Group. n.d. Qing Engraving. https://sheg.stanford.edu/history-assessments/qingengraving.

Tomlinson, Carol A., and Tonya R. Moon. 2013. Assessment and Student Success in a Differentiated Classroom. Alexandria, VA: Association for Supervision and Curriculum Development.

Verkest, Hugo. 2019. "Decoding the Discipline. Also for Children?" In Decoding the Disciplines in European Institutions of Higher Education: International and Interdisciplinary Approach to Teaching and Learning, edited by Sandra Chistolini, 27-33. Milan, Italy: FrancoAngeli.

Weiss, Robert S. 1994. Learning from Strangers: The Art and Method of Qualitative Interview Studies. New York: The Free Press.

Wineburg, Sam. 2001. Historical Thinking and Other Unnatural Acts: Charting the Future of Teaching the Past. Philadelphia: Temple University Press.

Wineburg, Sam. 2010. "Thinking Like a Historian." Teaching with Primary Sources Quarterly 3, no. 1:2-4. World Digital Library. 2014. Storming the Encampment at Gadan-Ola. https://www.wdl.org/en/item/7703/. Yin, Robert K. 2018. Case Study Research and Applications: Design and Methods. Los Angeles, CA: Sage.

Zunshine, Lisa E. 2010. "Lying Bodies of the Enlightenment: Theory of Mind and Cultural Historicism." In Introduction to Cognitive Cultural Studies, edited by Lisa E. Zunshine, 115-33. Baltimore, MD: Johns Hopkins University Press. 


\section{APPENDIX A}

\section{The Decoding Interview}

The decoding interview is used to get at underlying tacit ${ }^{1}$ knowledge and mental actions used in disciplinary skills.

Initially, interviewees usually offer superficial responses or respond as if they are speaking to someone who already knows what to do. The interviewer needs to ask probing questions to help the interviewee uncover and make explicit their tacit knowledge and mental actions used. In short, interviewers need to find out the mental "tools" interviewees use. To decode, interviewers should cycle among the following steps:

1. Ask interviewees to start from a specific, recent example when they used the mental action. Then ask, "What do you do?"

2. Imagine yourself doing what they describe. Are crucial steps being left out?

3. Ask questions where you don't understand. Probe where the interviewee cannot explain.

4. Summarize what the interviewees say; restate their points.

5. Reassure interviewees that it is okay to not be able to explain their tacit knowledge.

6. Gently redirect if the interviewees talk about how they teach their students, how they learned it, or if they launch into a lecture.

If the interview seems stuck, you might try the following additional questions, as appropriate:

1. How do you do that?

2. What does that tell you?

3. What information are you getting from that?

4. How do you know where to focus first?

5. Why is doing that important?

6. What do you do next? How does what you did before influence what you do next?

7. Are you asking a set of predetermined questions (based on some unmentioned heuristic ${ }^{2}$ )? What are the questions?

8. Do you choose an option (or strategy) from among several? If so, how did you know which to choose and which to leave out?

9. If all else fails, suggest an analogy for the mental action. Does this analogy properly represent the mental action? 
Key Points:

1. Confusion. As an interviewer you should not pretend to understand and skip over parts where you feel confused. When you feel confusion, you need to ask more probing questions to reveal the assumptions the interviewee is skipping over.

2. Digressions. You should try to avoid being sidetracked by digressions. Gently redirect interviews if the interviewees begin to digress into how they would teach students, or how they learned it, or if they launch into lectures.

3. Interviewee's comfort level. Notice if the interviewee gets uncomfortable from continued probing. The interviewee's discomfort is a signal that you have arrived at tacit knowledge that is difficult to put into words. Reassure them that their responses are appropriate, but continue to probe at this point.

4. Reassurance. Continually provide reassurance to the interviewee. Let them know that it is often hard to put into words exactly what they do, and they are doing a great job in the interview.

5. Working through silence. When you encounter silence, rephrase the question or ask a different question.

\section{Sources:}

Joan Middendorf and Leah Shopkow, Overcoming Student Learning Bottlenecks: Decode the Critical

Thinking of Your Discipline (Sterling, VA: Stylus Publishing, 2018), 48-59.

David Pace, The Decoding the Disciplines Paradigm: Seven Steps to Increased Student Learning

(Bloomington, IN: Indiana University Press, 2017), 37-48.

\section{Notes}

1. tacit: understood or implied without necessarily being stated

2. mental shortcuts used to make thinking quicker and easier 


\section{APPENDIX B}

HIS 399: Teaching and Learning of History - Spring 2020

Assignment: Decoding the Disciplines Assignment (Section 602 only)

Part 1 is due Monday, April 20, and is worth 5\% of your total course grade; Part Two is due Friday, May 1 and is worth $10 \%$ of your total course grade.

With this assignment, you will practice your skills of "decoding the discipline," by eliciting the thinking of a history student, and using that to identify "bottlenecks" or places where students get stuck in their disciplinary thinking. Armed with this knowledge, you will then develop a plan to help students get past their bottlenecks and develop into more advanced disciplinary thought.

This assignment has two parts.

\section{Part One: Conducting a Decoding the Disciplines Interview}

You will be paired up with an undergraduate student currently enrolled in HIS 100: The World to 1500. Those students have been selecting primary and secondary sources to write an analytical paper for their course. Schedule a time with your partner from HIS 100 between April 13-17. Conduct a Decoding the Disciplines interview over Microsoft Teams.

You will in interview your student partner using the following question: "How do you select credible sources for your history assignments?"

Use the prompts and steps from your Decoding the Disciplines handout, and take good notes during this interview. If your student partner consents, you might record this interview to allow you to go back over what happened and expand your notes.

Immediately after the interview, write a brief informal memo (around 1 page) on your initial reactions after the interview. What are important things you remembered from the interview? What are your initial thoughts about your students' disciplinary thinking? Potential bottlenecks your student faces? Things you might do to help move your student to more disciplinary thought?

You must submit to Blackboard both your notes and brief informal memo. Use pseudonyms for your student. You will be graded based on timeliness and good-faith effort for Part 1.

For our synchronous class meeting on Wednesday, April 22, you will work in small groups (of four to five). Before that class meeting, you should read the notes and informal memos from the members of your group. The small group discussion will treat your four to five students as a class of history students. In small group discussion, look for patterns of thought across the students. What are students doing well? What might their instructor (Dr. McBrady) need to follow-up on or address? What should Dr. McBrady's next teaching moves be in response to the information revealed in these Decoding interviews? 


\section{Part Two: Reflections following a Decoding the Disciplines Interview}

Based on the data collected across your whole small group (all four or five students) and your group discussion, you will write a formal reflection paper. This paper has three sections, and should be between 4-6 pages. Please label those sections in your reflection paper.

\section{Section 1: Students' Disciplinary Thought}

Describe the disciplinary thought of your small group's four or five students. What things did students do well? What were areas of bottlenecks? How many students had similar bottlenecks? You are encouraged to bring in specific evidence from interview notes or memos in this section.

\section{Section 2: Next Steps}

Advise Dr. McBrady on his next teaching steps in order to help these students further develop their disciplinary thought. Develop a plan for teaching activities he could use to help his students overcome bottlenecks. Cite literature (from AED 310, HIS 399, and elsewhere) to justify your pedagogical choices.

\section{Section 3: Reflections on Decoding the Disciplines}

What did you learn as a teacher from the process of conducting and reflecting upon a Decoding the Disciplines interview? What skills from this process could you utilize in your future practice as a teacher? 
Part Two will be graded based on the following rubric:

\begin{tabular}{|c|c|c|c|c|c|}
\hline & $\begin{array}{l}\text { Target } \\
(5)\end{array}$ & $\begin{array}{l}\text { Approaching } \\
\text { Target } \\
\text { (4) }\end{array}$ & $\begin{array}{l}\text { Acceptable } \\
(3)\end{array}$ & $\begin{array}{l}\text { Approaching } \\
\text { Acceptable } \\
\text { (2) }\end{array}$ & $\begin{array}{l}\text { Unacceptable } \\
\text { (1) }\end{array}$ \\
\hline $\begin{array}{l}\text { Section 1: } \\
\text { Analysis of } \\
\text { Students' } \\
\text { Disciplinary } \\
\text { Thought } \\
\\
\text { (based on } \\
\text { NCSS 3d and } \\
\text { edTPA } \\
\text { Rubric 11) }\end{array}$ & $\begin{array}{l}\text { The analysis } \\
\text { uses specific } \\
\text { examples to } \\
\text { demonstrate } \\
\text { patterns of } \\
\text { learning. } \\
\text { Analysis makes } \\
\text { clear references } \\
\text { to: } \\
\text { - concepts and } \\
\text { disciplinary } \\
\text { knowledge, } \\
\text { - skills of } \\
\text { inquiry, OR } \\
\text { - disciplinary } \\
\text { forms of } \\
\text { representation. } \\
\text { Analysis notes: } \\
\text { - individual } \\
\text { students, } \\
\text { - whole class, } \\
\text { AND } \\
\text { - subset groups. }\end{array}$ & $\begin{array}{l}\text { Analysis makes } \\
\text { clear references } \\
\text { to: } \\
\text { - concepts and } \\
\text { disciplinary } \\
\text { knowledge, } \\
\text { - skills of } \\
\text { inquiry, OR } \\
\text { - disciplinary } \\
\text { forms of } \\
\text { representation. } \\
\text { Analysis notes: } \\
\text { - individual } \\
\text { students, } \\
\text { - whole class, } \\
\text { OR } \\
\text { - subset groups. }\end{array}$ & $\begin{array}{l}\text { The analysis } \\
\text { focuses on what } \\
\text { students did } \\
\text { right AND } \\
\text { wrong. } \\
\text { Analysis makes } \\
\text { clear references } \\
\text { to: } \\
\text { - concepts and } \\
\text { disciplinary } \\
\text { knowledge, } \\
\text { - skills of } \\
\text { inquiry, OR } \\
\text { - disciplinary } \\
\text { forms of } \\
\text { representation. }\end{array}$ & $\begin{array}{l}\text { The analysis } \\
\text { focuses on } \\
\text { what students } \\
\text { did right OR } \\
\text { wrong. } \\
\text { Analysis makes } \\
\text { limited } \\
\text { references to: } \\
\text { • concepts and } \\
\text { disciplinary } \\
\text { knowledge, } \\
\text { - skills of } \\
\text { inquiry, OR } \\
\text { - disciplinary } \\
\text { forms of } \\
\text { representation }\end{array}$ & $\begin{array}{l}\text { Analysis is } \\
\text { superficial or } \\
\text { not supported } \\
\text { by the evidence } \\
\text { from notes or } \\
\text { memos. }\end{array}$ \\
\hline
\end{tabular}




\begin{tabular}{|c|c|c|c|c|c|}
\hline $\begin{array}{l}\text { Section 2: } \\
\text { Next Steps } \\
\text { Knowledge } \\
\text { of Students }\end{array}$ & $\begin{array}{l}\text { Candidate } \\
\text { justifies why } \\
\text { learning tasks } \\
\text { are appropriate } \\
\text { using specific } \\
\text { examples from } \\
\text { students' } \\
\text { interviews. }\end{array}$ & $\begin{array}{l}\text { Candidate } \\
\text { justifies why } \\
\text { learning tasks are } \\
\text { appropriate and } \\
\text { based on } \\
\text { students' } \\
\text { thoughts as } \\
\text { revealed in } \\
\text { interviews. }\end{array}$ & $\begin{array}{l}\text { Candidate } \\
\text { justifies learning } \\
\text { tasks with } \\
\text { limited } \\
\text { attention to } \\
\text { students' } \\
\text { thoughts as } \\
\text { revealed in } \\
\text { interviews. }\end{array}$ & $\begin{array}{l}\text { Candidate's } \\
\text { justification of } \\
\text { learning tasks } \\
\text { represents a } \\
\text { deficit view of } \\
\text { students. }\end{array}$ & $\begin{array}{l}\text { Candidate's } \\
\text { learning tasks } \\
\text { are superficial } \\
\text { or not } \\
\text { supported by } \\
\text { the evidence } \\
\text { from notes or } \\
\text { memos. }\end{array}$ \\
\hline $\begin{array}{l}\text { Section 2: } \\
\text { Next Steps } \\
\text { Explanation } \\
\text { of Planning: } \\
\text { Research and } \\
\text { Theory } \\
\\
\text { (based on } \\
\text { NCSS } \\
\text { Element 3c } \\
\text { and edTPA } \\
\text { Rubric 3) }\end{array}$ & $\begin{array}{l}\text { Candidate uses } \\
\text { research and/or } \\
\text { theory to justify } \\
\text { their inclusion } \\
\text { of: } \\
\text { - disciplinary } \\
\text { knowledge, } \\
\text { - inquiry, OR } \\
\text { - forms of } \\
\text { representation. }\end{array}$ & $\begin{array}{l}\text { Candidate's } \\
\text { justification is } \\
\text { supported by } \\
\text { principles from } \\
\text { research and/or } \\
\text { theory. }\end{array}$ & $\begin{array}{l}\text { Candidate } \\
\text { makes } \\
\text { connections to } \\
\text { research and/or } \\
\text { theory. }\end{array}$ & $\begin{array}{l}\text { Candidate } \\
\text { makes } \\
\text { superficial } \\
\text { connections to } \\
\text { research and/or } \\
\text { theory. }\end{array}$ & $\begin{array}{l}\text { Candidate } \\
\text { makes no } \\
\text { connections } \\
\text { to research } \\
\text { and/or theory } \\
\text { in their } \\
\text { explanation. }\end{array}$ \\
\hline $\begin{array}{l}\text { Section 3: } \\
\text { Reflections } \\
\text { on Decoding } \\
\text { the } \\
\text { Disciplines }\end{array}$ & $\begin{array}{l}\text { Candidates } \\
\text { identifies } \\
\text { specific skills } \\
\text { and practices } \\
\text { from this } \\
\text { experiences and } \\
\text { justifies how to } \\
\text { incorporate } \\
\text { them into their } \\
\text { practice, with } \\
\text { specific } \\
\text { examples. }\end{array}$ & $\begin{array}{l}\text { Candidate } \\
\text { identifies specific } \\
\text { skills and } \\
\text { practices from } \\
\text { this experience } \\
\text { that impact their } \\
\text { practice and } \\
\text { justifies how to } \\
\text { incorporate } \\
\text { them into their } \\
\text { practice. }\end{array}$ & $\begin{array}{l}\text { Candidate } \\
\text { identifies } \\
\text { specific skills } \\
\text { and practices } \\
\text { from this } \\
\text { experience that } \\
\text { impact their } \\
\text { practice. }\end{array}$ & $\begin{array}{l}\text { Candidate } \\
\text { considers } \\
\text { generally how } \\
\text { this experience } \\
\text { could impact } \\
\text { their practice. }\end{array}$ & $\begin{array}{l}\text { Candidate } \\
\text { ignores the } \\
\text { impact this } \\
\text { experience } \\
\text { could have on } \\
\text { their practice } \\
\text { or draws } \\
\text { incorrect } \\
\text { conclusions. }\end{array}$ \\
\hline
\end{tabular}


APPENDIX C

\section{HIST 399 Pre- \& Post-Assessment}

Spring 2020

Directions: Use the document and background information to answer the questions below.

\section{Storming the Encampment at Gadan-Ola}

Context: The Qianlong Emperor of China commissioned this print in the $18^{\text {th }}$ century to commemorate his military victories. The print was made by etching a copper plate, filling the grooves with ink, and pressing the plate on paper to transfer the image. The Qianlong Emperor was of the Qing dynasty. The print shows the Qing army attacking enemy soldiers from the Zunghar Empire in Central Asia.

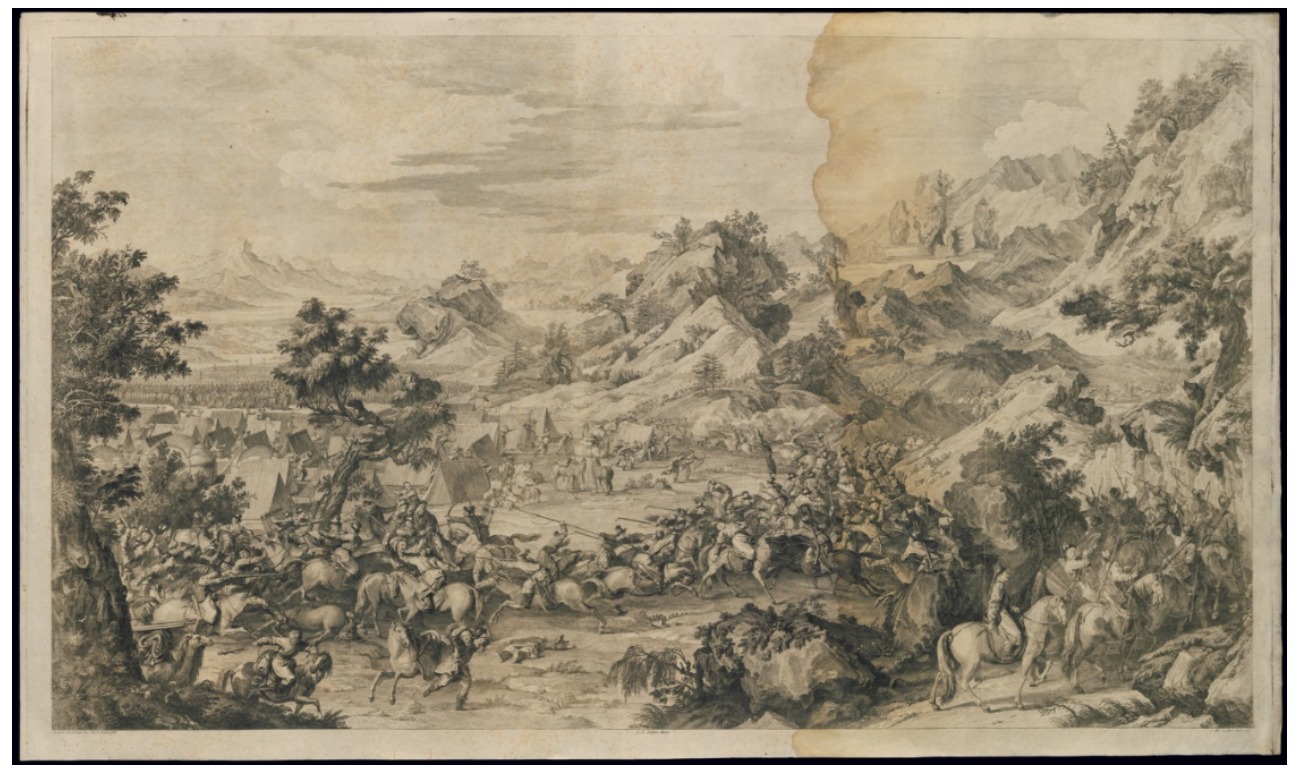

Title: Storming the Encampment at Gadan-Ola

Date: $1765-1769$

Artist: Jacques-Philippe Le Bas (based on a painting by Giuseppe Castiglione)

Place: Paris (based on a painting made in China)

Source: World Digital Library. https://www.wdl.org/en/item/7703/

What skill and/or concept might be best taught with this image? Why? 
How could you use this image to teach students the skill/concept you identified?

Claim: The print Storming the Encampment at Gadan-Ola is a reliable piece of evidence for historians to use to understand what occurred during the battle between Zunghar soldiers and the Qing army.

Do you agree or disagree? (Circle one.)

Briefly support your answer:

This pre-assessment modified from materials available through the Stanford History Education Group. 
Rubric for the Pre- and Post-Assessment

Question 1

\begin{tabular}{|l|l|}
\hline Proficient & $\begin{array}{l}\text { Student mentions a discrete historical thinking } \\
\text { skill (ex. sourcing or contextualizing - NOT } \\
\text { corroboration) or a relevant historical concept } \\
\text { and justifies this with an explanation. }\end{array}$ \\
\hline Emergent & $\begin{array}{l}\text { Student mentions a discrete historical thinking } \\
\text { skill or concept, but does not adequately } \\
\text { connect the print to this concept. }\end{array}$ \\
\hline Basic & $\begin{array}{l}\text { Student either does not mention a discrete skill } \\
\text { or mentions a fact, not a concept. }\end{array}$ \\
\hline
\end{tabular}

\section{Question 2}

\begin{tabular}{|l|l|}
\hline Proficient & $\begin{array}{l}\text { Student identifies specific practices that are } \\
\text { effective, student-centered ways for teaching } \\
\text { the desired outcome (ex., concept formation } \\
\text { for a concept, modeling a skill). }\end{array}$ \\
\hline Emergent & $\begin{array}{l}\text { Student's plans for teaching are vague, fact- } \\
\text { centric, or teacher-centric. }\end{array}$ \\
\hline Basic & $\begin{array}{l}\text { Student does not provide relevant teaching } \\
\text { practices for their identified concept or skill, or } \\
\text { provides teaching practices that are } \\
\text { inappropriate for the desired outcome (ex., } \\
\text { modeling a concept). }\end{array}$ \\
\hline
\end{tabular}

\section{Question 3}

\begin{tabular}{|l|l|}
\hline Proficient & $\begin{array}{l}\text { Student disagrees with the claim and explains } \\
\text { how the emperor commissioning the prints to } \\
\text { commemorate his victories may have led the } \\
\text { artist to portray the battle in a way that was } \\
\text { favorable to the Qing army. }\end{array}$ \\
\hline Emergent & $\begin{array}{l}\text { Student disagrees with the claim, notes that the } \\
\text { emperor commissioned this print to celebrate } \\
\text { his victories, but does not provide an adequate } \\
\text { or complete explanation for why this would } \\
\text { lead them to question the reliability of the } \\
\text { document. }\end{array}$ \\
\hline Basic & $\begin{array}{l}\text { Student either agrees with the claim or } \\
\text { disagrees but does not provide a relevant } \\
\text { explanation. }\end{array}$ \\
\hline
\end{tabular}

